\title{
Empirical Study on Management Equity Incentive and Investment Efficiency Based on Shanghai and Shenzhen A-share listed companies
}

\author{
Han dong-ping, Guo cai-cai, Zhao yue \\ School of Management, Harbin Institute of Technology, P.R.China, 150001
}

\begin{abstract}
More and more listed companies are trying equity incentive in China, but there has not yet formed a unified understanding of the impact of equity incentive on investment efficiency. Based on the theory of management power, using the investment model of Richardson and choosing Shanghai and Shenzhen A-share listed companies which has implemented with equity incentive from 2006 to 2015 as research sample, we verify the impact of equity incentive on investment efficiency. It is proved that the management equity incentive has a significant negative impact on the investment efficiency of the enterprise through comparing the relationship between equity incentive and investment efficiency of the two types of listed companies, overinvestment and underinvestment. The effect of the relationship between the equity incentive and the investment efficiency is different according to different properties of actual controller. Compared with state holding companies, it is weak that the negative relationship between equity incentive and the investment efficiency in non-state holding companies. The size of listed companies will also influence the relationship. The final results show that the implementation of equity incentives does no help to curb overinvestment or ease the underinvestment.
\end{abstract}

Keywords-Managerial Equity Incentive; Investment Efficiency; Management authority theory

\section{INTRODUCTION}

Equity incentive has been implemented for many years and gradually accepted by listed companies. The main purpose of the implementation of equity incentive is to promote managers making decisions which will benefit shareholders, reduce information asymmetry and moral hazard, and improve the investment efficiency. With the maturity of China's securities market, information disclosure transparency of listed companies has been paid more and more attention by stakeholders. With the increasing attention of external investors, managers will pay more attention to current profits and losses, resulting in insufficient investment [1]. Managerial equity incentive as a way of control gradually favored by many large companies, but there has not yet formed a unified understanding of the impact of equity incentive on the efficiency of investment in listed companies. Gaver et al found that long-term incentive contracts in growth companies can reduce agency costs between managers and shareholders due to information asymmetry [2]. The improvement of the internal control quality of the enterprise has a positive effect on the improvement of investment efficiency [3]. Roll argues that equity incentives will improve the effectiveness of stock prices and improve the company's resource allocation.
Because the greater the degree of equity incentives, the greater the sensitivity of corporate investment to stock prices. Stock options make the company more exposed to the active options market, which will promote the perfection of capital markets and reduce insider trading [4]. Luo et al pointed out that equity incentive has a positive effect on investment, and that there is an endogenous relationship between them[5].

Different from the scholars above, some scholars found that equity incentive will lead to inefficient investment. Strobl found that shareholders' concerns about equity incentive will lead to overinvestment. Because the risk of cash flow make both sides of the transaction want to become information insiders. Meanwhile, excessive investment can make external investors obtain more information by accepting projects whose net present value is positive or negative [6]. Wang et al selected manufacturing companies listed on small board as the object of study and found that the implementation of equity incentive made the company's managers more inclined to excessive investment, which means equity incentive does no help in reducing agency costs [7].

Wang and Huang proposed that there is a "U" type relationship between equity incentive and corporate value [8]. Most of the domestic scholars are concerned with the implementation of equity incentive and its impact on the performance of enterprises, while there is no conclusive conclusion in the study of investment efficiency. In addition, the degree of equity incentive was measured from the perspective of management shareholding ratio, but seldom from the perspective of managerial stock options or restricted stock.

The significance of this study includes: First, It helps clarify the impact of equity incentives on investment efficiency. This research studies the impact of equity incentive on investment efficiency through empirical analysis, to make enterprises understand the consequences of the implementation of equity incentive. Second, it helps shareholders to monitor the management. Based on the managerial power theory, this study verifies the behavior of the management in the perspective of the size of enterprises and the property of actual controller, to help business owners understand the managers' decision-making path and develop supervision mechanisms. Third, it helps the listed companies to improve the incentive and restraint mechanism. It provides empirical evidence to optimize the corporate governance structure and pay mechanism, through analyzing the effectiveness of equity incentive. 


\section{THEORETICAL ANALYSIS AND RESEARCH HYPOTHESIS}

\section{A. Theoretical analysis}

Jensen first introduced the principal-agent theory into the study of corporate governance, and pointed out that managers and shareholders have conflicting goals [9]. When the interests of managers and shareholders are inconsistent, there may be overinvestment and underinvestment. In addition, when enterprises have occupied large market share, the management may pursue the scale of the expansion, while ignoring the interests of shareholders. If the company's capital expenditure budget is large, managers are more inclined to make overinvestment decisions [10]. The information asymmetry between enterprise managers and shareholders will lead to managers do harm to the interests of shareholders, which prompted the equity incentive gradually adopted by listed companies. The disclosure of the company's future share price information will have an impact on investment efficiency [11]. Faced with the same inefficient investment, there is a difference in the amount of investment between conservative and non-conservative companies [12]. Equity incentive is to let executives and core employees hold shares to drive them work hard to reduce unethical behavior. It changes their choice of risk portfolio by changing the management's volatility in stock returns (Vega) and stock price sensitivity (Delta).

The principal-agent theory points out that there is a difference between the management's and the shareholders' objectives: the shareholders are committed to the growth of wealth, while the management is mainly focused on the increase in salaries and the reduction of risk. At the same time, according to the information asymmetry theory, management is in the superior position of information, and shareholders are difficult to fully monitor the behavior of management, which is in a relatively inferior position. The implementation of equity incentive cannot completely reduce agency costs and improve investment efficiency. There are two main reasons including: First, according to the managerial power theory, the management expects to obtain excess returns through the implementation of equity incentive and may make decisions that are not conducive to the company for their own interests. Second, according to the effective market theory, China's capital market has not developed completely. Therefore, if the stock can not reflect the real market value, the effectiveness of equity incentive need to be carefully considered and the impact of equity incentive on the efficiency of investment in listed companies also need in-depth discussion.

Based on the analysis above, the theoretical analysis of the correlation between equity incentive and investment efficiency can be examined from two aspects. First, management can use power to arrange the payment contract, so that equity incentive can be adopted as a payment form in listed companies. Second, it analyzes the specific impact of equity incentive on the investment efficiency in listed companies. After the literature review, we found out two ways of effect that equity incentive has on investment efficiency. Therefore, this study will discuss from the following two aspects:

(1) Payment contract and equity incentive. In the enterprises whose management and ownership are separated, management power will affect the design of payment system and the market reaction depends on if market participants have realized management's rent-seeking. Institutional investors play a greater role of in market orientation [13]. The increasing power of the management will lead to the company's policy become more beneficial to the management and will damage shareholders' interests. Managers may adopt equity incentive policies to achieve excess residual income. It cannot be completely satisfied that the effectiveness of the capital market, the fact that the board is responsible and independent and the effectiveness of shareholder complaint mechanism, so the management can use its power to influence the payment system [14]. According to managerial power theory, the implementation of equity incentive can be regarded as the welfare that the managers arrange for themselves, resulting in excessive payment of enterprise resources. In the long run, this excessive payment will lead to the reduction of enterprise value and lead to inefficient investment behavior.

(2) Equity incentive and investment efficiency. Due to the lower conditions of exercising equity incentive, equity incentive cannot lead to the improvement of investment efficiency. Quan et al point out that private benefits obtained by the management of state-owned enterprises are positively related to their power [15]. The management will be more sensitive to manipulate performance and financial data with greater power. Different properties of the controller lead to differences in management power, so that the effect of equity incentive on investment efficiency is also different. Because of the greater management power in state-owned enterprises, it is easier to capture private profits through equity incentive, so the equity incentive has more negative effects in state-owned enterprises. When investors analyze companies with non equity incentive, the investment approach can be seen as a factor [16]. Executive payment is the main motivation for management violations. To some extent, there is a game of interests and conflicts of target between management and shareholders. The extension of managerial power may lead to management adventurism and lead to inefficient investment.

\section{B. Research Hypothesis}

According to managerial power theory, managers may strive to improve individual income and make non optimal decisions. Therefore, equity incentive may not have a positive effect on investment efficiency. The reasons including: First, China's capital market is not perfect, so that the option can not reflect the real value. When the incentive object is not optimistic about the market, the incentive measures will be ineffective. Second, when the listed companies implement the equity incentive, the exercise conditions are linked with the performance of listed companies. In this condition, management tend to manipulate the operating and financing behavior in order to achieve the profit target, place personal interests above listed companies long-term and overall interests and ultimately make inefficient investment [7]. Goldman's research also suggests that equity incentive will enable management to boost stock prices in the short term[17].

In summary, in the current domestic market conditions, equity incentive is difficult to reduce conflicts. Management may make use of managerial power to choose the project that 
can bring the excess return. However, these projects neither NPV as positive or negative, may cause inefficient investment. Equity incentive is implemented to reduce agency costs and promote the interests of shareholders and management to tend to be consistent. The expansion of management power may lead to excessive profits by other means. If the stock option cannot bring benefit to the management, equity incentive cannot achieve the desired effects. It is difficult for the shareholders to fully supervise the management's behavior. The investment decision deviates from the expected normal investment will reduce the investment efficiency. Accordingly, the first hypothesis is put forward.

H1: Equity incentive is negatively related to corporate investment efficiency

Different implementation effect of equity incentive may lead to different management decisions and ultimately affect investment efficiency. The property right is clear in non stateowned enterprises, management behaviors are under supervision by the controlling shareholders and other small shareholders. The level of internal control is low. Adverse selection activities are constrained. So the problem of inefficient investment is lighter. Management in non-stateowned companies is usually produced by the market mechanism of competition, so non-state-owned enterprises pay more attention personal occupation target and the companies' interests. Equity incentive is an important part of their total payment, so equity incentive has certain effect.

According to asymmetric information theory, the information transparency of state-owned enterprises is relatively low. Management behavior is difficult to supervise so that equity incentive may become a way of seeking interests for managers. Equity incentive is likely to have a negative effect on investment efficiency. In addition, compared with the non-state-owned enterprises, management power of state-owned enterprises is more centralized. Managers can use power easier which can bring their own interests. Equity incentive may decline the value of listed companies by the leading their investment deviate from the expected results, resulting in inefficient investment. Accordingly, the second hypothesis is put forward.

H2: Compared with state-owned enterprises, the negative relationship between equity incentive and enterprise investment efficiency is weaker in non-state-owned enterprises.

In enterprises of different sizes, the degree of information asymmetry between management and shareholders are different. The shareholders supervision of management will also affect the management making investment decisions, thereby affecting the investment efficiency of listed companies. Along with the enterprise scale increases, the degree of difference between target shareholders and management increases resulting in the increase of shareholders' supervision, management decisions are easy to be known by shareholders [18], so the equity incentive has relatively small negative effect on investment efficiency. The management will consider that making a series of decisions that will harm shareholders interests may cause dismissal, demotion or other bad things for themselves. So they will adjust the behavior, tend to invest in the project which can increase shareholder wealth. Thereby it will reduce the decisions that are harmful to shareholders interests. In the long run, it is beneficial to improve investment efficiency.

In addition, in small enterprises, managerial power is greater. Equity incentive may lead to the reduction of companies' value, resulting in the investment of listed companies deviate from the expected results. It will also reduce enterprise investment efficiency. In large scale companies, information are of high transparency and the design of supervision and management system may be more systematic and comprehensive [19]. So the problems such as profit manipulation, blind investment, on-the-job consumption and others can be effectively curbed. The negative effects of equity incentive on investment efficiency are not very serious. But in small companies, management mechanism is not perfect. When given large amount of equity incentive and lack of supervision, managers are more likely to do adverse selection that deviates from enterprise's goal if they are. They will put the company's capital into the projects that do not match with the company's risk level which will reduce investment efficiency. Accordingly, the third hypothesis is put forward.

H3: Company's size plays a positive moderating role in the relationship between equity incentive and corporate investment efficiency.

\section{3. EMPIRICAL RESEARCH}

\section{A. Sample Selection}

China began to implement the reform of non tradable shares in 2006. The SFC promulgated the "equity incentive management approach of listed companies". Since then, it is allowed management shares can be traded, which provides an opportunity for the management to obtain controlling benefits in the trading market. Therefore, the long-term incentive effect of equity incentive plan may be different from 2006. So this study selected Shanghai and Shenzhen A-share listed companies which has implement equity incentive as the research object. The sample time ranges from 2006 to 2015. There are totally 495 observations in ten years. The sample data does not include the ST class and the *ST class listed companies because of their unusual management behavior and the probably impact on the investment efficiency. The data was collected from RESSET Financial database and CSMAR database and some missing data was from the companies' website and CNINF. All data analysis was completed by Excel 2010, Eviews and SPSS16.0 statistical analysis software.

\section{B. Model Building}

Formula 3-1 that Core and Guay, Bergstresser used is more suitable for equity incentive [20]-[21], so this study will also use it. We calculate the degree of equity incentive with the ratio of management equity to total management pay:

$$
\text { Incent }_{i t}=\frac{0.01 \times \text { price }_{i t} \times\left(\text { share }_{i t}+\text { option }_{i t} \times \text { delta }_{i t}\right)}{0.01 \times \text { price }_{i t} \times\left(\text { share }_{i t}+\text { option }_{i t} \times \text { delta }_{i t}\right)+\text { remuneration }_{i t}}
$$


Among them, priceit is the company stock price at the end of the $t$ year, shareit is the amount of management holding stock at the end of the $t$ year (including restricted stock), optionit refers to the amount of the company's management stock option at the end of the $t$ year, deltait is the partial derivative of the option value to the stock price, remuneration is the payment that management obtained from the company in the form of cash in the $t$ year.

As Tobin Q and Wugler model has sample survivor bias probability, case will appear low investment efficiency company has no chance to be choose as sample, which makes the investment efficiency results calculating from the samples are above the true results. So according to accuracy considerations, this research studies the problem of inefficient investment of Listed Companies in China using Richardson model. In Richardson model, enterprise investment expenditure mainly consists of two parts:, the first part is the maintenance investment, which is necessary consume investment in order to maintain the normal use of the business premises, equipment and others, such as depreciation of fixed assets and amortization of intangible assets. The other part is the new investment this year, the amount of investment needed to implement the new project. Richardson expected (normal) investment model, as shown in (3-2):

$$
\begin{aligned}
\text { Invest }_{i t}= & \alpha_{0}+\alpha_{1} \text { Grouth }_{l, t-1}+\alpha_{2} \text { Cash }_{i, t-1}+\alpha_{3} \text { Rog }_{i, t-1}+\alpha_{4} L e v_{i t-1}+\alpha_{5} \text { Size }_{i t-1}+\alpha_{6} \operatorname{Ret}_{i t-1} \\
& +\alpha_{7} \text { Age }_{i t-1}+\alpha_{8} \text { Invest }_{i t-1}+\text { year }+\varepsilon_{i t}
\end{aligned}
$$

In the model (3-2), the fit value is on behalf of expected investment at the year of $t$. If the regression residual value is positive, that enterprises investment is beyond the sum of enterprise maintenance investment and investment in the project whose NPV is positive. That is excessive investment (Overinvest). On the contrary, is lack of investment (Underinvest). The absolute value of the residual of the model (3-2) is set. Set the investment efficiency variable as InvEff, and the larger the InvEff, the greater the gap of actual investment and expected (normal) investment, the lower the investment efficiency. After taking the absolute value of the residuals, we make regression analysis of investment efficiency and equity incentive. In the light of these models and the actual situation of Listed Companies in China, the following models are constructed:

$$
\begin{aligned}
\text { InvEff } & =\beta_{0+} \beta_{1} \text { Incentit }+\beta_{2} F C F_{i t-1}+\beta_{3} \text { Growth }_{i t-1}+\beta_{4} \text { Size }_{i t-1}+\beta_{5} \text { Roa }_{i t-1}+\beta_{6} \text { Cash }_{i t-1} \\
& +\beta_{7} \text { Ounnership }_{i t-1}+\theta_{i t}
\end{aligned}
$$

Then we study the governance effect of equity incentive through two sets of state-owned and non-state-owned holding data. In the model (3-3), selected FCF (free cash flow), Size (scale) and Growth (operating income growth rate), Roa(asset net interest rate), Cash (monetary assets ratio),

\begin{tabular}{|c|c|c|}
\hline Variable name & $\begin{array}{l}\text { Variabl } \\
\text { e code }\end{array}$ & Explain \\
\hline $\begin{array}{c}\text { Revenue } \\
\text { growth rate }\end{array}$ & Growth & $\begin{array}{c}\text { (operating income for the previous year - revenue last year) / last year's } \\
\text { operating income }\end{array}$ \\
\hline $\begin{array}{l}\text { Stock price at } \\
\text { the end of the } \\
\text { year }\end{array}$ & Price & Closing price of company stock at the end of the year \\
\hline $\begin{array}{l}\text { Stock option } \\
\text { quantity }\end{array}$ & Option & Share options held by management at the end of the year \\
\hline $\begin{array}{l}\text { Option value } \\
\text { sensitivity }\end{array}$ & delta & The primary bias of the underlying asset price on the option value \\
\hline Stock quantity & share & $\begin{array}{l}\text { The number of shares held by management at the end of the year } \\
\text { (including restricted shares) }\end{array}$ \\
\hline $\begin{array}{c}\text { Cash } \\
\text { compensation }\end{array}$ & $\begin{array}{c}\text { remune } \\
\text { ration }\end{array}$ & $\begin{array}{c}\text { Cash compensation received by management from the company in those } \\
\text { years }\end{array}$ \\
\hline Equity & & Incent $=\frac{0.01 \times \text { price }_{i t} \times\left(\text { share }_{i t}+\text { option }_{i t} \times \text { delta }_{i t}\right)}{}$ \\
\hline incentive & incent & Incen $u_{i t}=\overline{0.01 \times \text { price }_{i t} \times\left(\text { share }_{i t}+\text { option }_{i t} \times \text { delta }_{i t}\right)+\text { remuneration }_{i t}}$ \\
\hline $\begin{array}{c}\text { New } \\
\text { investment }\end{array}$ & invest & $\begin{array}{l}\text { New investment (= the current construction of fixed assets, intangible } \\
\text { assets and other long-term assets and disposal of fixed assets, intangible } \\
\text { assets and other long-term assets to recover the cash net current } \\
\text { depreciation of fixed assets, intangible assets and other long-term assets } \\
\text { amortization) / total assets at the beginning of the year }\end{array}$ \\
\hline $\begin{array}{l}\text { Investment } \\
\text { efficiency }\end{array}$ & InvEff & $\begin{array}{l}\text { Model (2) the absolute value of the residuals of regression, the greater the } \\
\text { absolute value, the lower the efficiency of investment }\end{array}$ \\
\hline $\begin{array}{c}\text { Monetary } \\
\text { assets ratio }\end{array}$ & Cash & Monetary Fund / total assets at the end of the year \\
\hline $\begin{array}{c}\text { Net asset } \\
\text { interest rate }\end{array}$ & Roa & Net profit / year-end total assets \\
\hline $\begin{array}{l}\text { Asset liability } \\
\text { ratio }\end{array}$ & Lev & Liabilities / total assets of listed companies at the end of 2013 \\
\hline company size & Size & At the end of the listed company's total assets of natural logarithm \\
\hline Stock return & Ret & $\begin{array}{l}\text { (closing price at the end of this year - closing price at the end of last year) } \\
\text { / closing price of shares at the end of last year }\end{array}$ \\
\hline Listing age & Age & Listed companies have been listed for a fixed number of years \\
\hline Free cash flow & FCF & $\begin{array}{l}\text { (net operating profit after tax }+ \text { depreciation and amortization) - (capital } \\
\text { outlay + working capital increase) }\end{array}$ \\
\hline $\begin{array}{l}\text { Ownership } \\
\text { concentration }\end{array}$ & $\begin{array}{l}\text { Owners } \\
\text { hip }\end{array}$ & $\begin{array}{l}\text { Top } 10 \text { shareholders, shareholding ratio, shareholding ratio = holding } \\
\text { shares / company total number of shares }\end{array}$ \\
\hline Particular year & Year & A dummy variable, if a year, is 1 , or 0 \\
\hline
\end{tabular}
ownership(ownership concentration) as control variables. The definitions of each variable are shown in table 3-1:
Table 3-1. Variable names and descriptions

\section{Descriptive Statistics}

As shown in table 3-2, the average equity incentive (Incent) of Sample Firms is about 0.261, indicating that the average incentive level of Sample Firms is not very high, which may be due to immature capital markets in China. Because of the inefficiency of capital market and the imperfect legal system of factor market, the actual impact of equity incentive on listed companies is not clear, so listed companies have not expanded the proportion of equity incentive. In addition, the standard deviation of equity incentive sample is not big, which shows that the incentive level of Sample Firms equity incentive does not change obviously. The age of the listed companies (Age), the company scale (Size), stock returns (Ret) and free cash flow (FCF) standard deviation is larger, which indicates that the Sample Firms historical foundation is uneven, the internal operation of large difference. Stock returns and free cash flow are very large, which shows that there is a gap between the operating conditions of listed companies and the market reaction. The average new investment of the previous year (Investt-1) and the new investment of this year (Invest) were 0.104 and 0.097 , indicating that the listed company which implemented equity incentives in the previous year has reduced is investment. In addition, the standard deviation and average value of the net asset interest rate (Roa) of listed companies are relatively small, which shows that the profitability of listed companies is not high, but relatively stable. The average concentration of ownership is 0.612 , indicating that the concentration of equity concentration of 
listed companies is above 50\%, relatively concentrated. Besides, the listed company's monetary assets ratio (Cash) and asset liability ratio (Lev) standard deviation are less than 2, reflecting the listed company's asset structure has changed little, which has implement equity incentive. To sum up, the incentive level of listed companies with equity incentive is not high, but the internal environment is quite different.

Table 3-2. Descriptive statistics

\begin{tabular}{|c|c|c|c|c|c|}
\hline & $\begin{array}{l}\text { Sample } \\
\text { size }\end{array}$ & $\begin{array}{l}\text { Minimum } \\
\text { value }\end{array}$ & $\begin{array}{l}\text { Maximum } \\
\text { value }\end{array}$ & $\begin{array}{l}\text { Mean } \\
\text { value }\end{array}$ & $\begin{array}{l}\text { Standard } \\
\text { deviation }\end{array}$ \\
\hline Incent & 495 & 0.000 & 0.958 & 0.261 & 0.192 \\
\hline Growth & 495 & -0.663 & 2.573 & 0.272 & 0.328 \\
\hline Cash & 495 & 0.000 & 0.903 & 0.240 & 0.174 \\
\hline Roa & 495 & -0.187 & 0.434 & 0.077 & 0.059 \\
\hline Lev & 495 & 0.024 & 0.899 & 0.377 & 0.192 \\
\hline Size & 495 & 19.418 & 25.391 & 21.618 & 0.994 \\
\hline Ret & 495 & -0.790 & 5.660 & 0.264 & 0.851 \\
\hline FCF & 495 & -7.279 & 6.297 & 0.084 & 1.024 \\
\hline Invest & 495 & -0.080 & 0.645 & 0.097 & 0.099 \\
\hline Invest $_{\mathrm{t}-1}$ & 495 & -0.080 & 4.557 & 0.104 & 0.228 \\
\hline Age & 495 & 0.000 & 21.129 & 5.963 & 5.049 \\
\hline Ownership & 495 & 0.179 & 1.000 & 0.612 & 0.153 \\
\hline
\end{tabular}

\section{Regression Analysis}

According to the formula (3-2), we choose new investment of this year (Invest) as the dependent variable, the operating income growth rate (Growth) as independent variables, the rest of variables as control variables except the equity concentration degree. According to model 3-2, the multiple regression results in the difference between the actual investment and the expected investment (residual). 191 samples' residual values are positive, while other 304 samples' are negative, which shows that underinvestment exceed overinvestment. Set the residuals as variables RES1. RES1 is the unexpected part of investment, the minimum residual value is about -0.527 , which belongs to the lack of investment, and the maximum is about 0.485 , which indicates the part of excessive investment in the projects whose NPV is negative. But the average is close to 0 and the standard deviation is small, suggesting that from the whole point of view, investment of Listed Companies with implementation of equity incentive is in the expected range. The investment of listed companies deviates from normal investment not very obviously. The probability of underinvestment or overinvestment in the sample is relatively low.

Use non parameters in SPSS for residual data. Make K-S normality test according to the year and the results are shown in table 3-3, each year the sample residual test Sig value is greater than $1 \%$, being confidence at the $99 \%$ level. Therefore, reject the null hypothesis and the samples meet the normal distribution. Because the sample distribution satisfies the basic conditions, we can apply the index set in this paper for the next regression analysis.
Table 3-3. Test data of normality

\begin{tabular}{ccccccccccc}
\hline & 2006 & 2007 & 2008 & 2009 & 2010 & 2011 & 2012 & 2013 & 2014 & 2015 \\
\hline $\begin{array}{c}\text { Sample } \\
\text { size }\end{array}$ & 3 & 8 & 29 & 30 & 29 & 42 & 89 & 131 & 65 & 69 \\
$\begin{array}{c}\text { Statistic } \\
\text { The } \\
\text { value } \\
\text { of Sig }\end{array}$ & 0.620 & 0.800 & 1.018 & 1.160 & 0.539 & 1.098 & 1.591 & 1.560 & 1.562 & 1.156 \\
\hline
\end{tabular}

According to the formula (3-3), set the residual absolute value of the last step regression results as the explanatory variable which is investment efficiency. Set equity incentive as explanatory variables, corporate free cash flow, operating income growth rate, monetary assets ratio, asset net interest rate, company size, ownership concentration as control variables. Construct the linear regression of the model. Table 3-4 shows regression results:

As is shown in table 3-4, the adjustment R2 is 0.088, although the adjustment R2 is not large, the model passed the F test. So it can be concluded that the model is significant. The coefficient test shows that the Sig values of three independent variables are all less than 0.05 and the coefficients are significant at the $95 \%$ confidence level. The coefficient of equity incentive and revenue growth rate is positive, which shows that raising equity incentive will have negative effect on the investment efficiency of listed companies. It is consistent with our research hypothesis. It indicates that the enterprise owner plans to ease the goal conflict between the agent and the owner through equity incentive plan is not feasible. Equity incentive broadens the way for management to capture excess returns. In the long run, it is not conducive to enterprise value and investment efficiency. But this paper is different from the conclusions of some studies [22]-[23]. These studies show that equity incentive can improve the enterprise investment efficiency. The reasons for this difference may be economic growth, policy change, different investment philosophy and other reasons. The greater the growth rate of business income, the larger probability of inefficient investment. It may be because that the business income growth results in the increase in power management, leading management choose projects that deviate from the expected investment. The coefficient of ownership concentration is positive but not significant, indicating that the increase of ownership concentration cannot lead to the growth of enterprise investment efficiency. This is probably because of the high degree of ownership concentration makes shareholder supervision weak. Management may use power to make decisions that is beneficial to management's interests, and these decisions cannot bring efficiency. 
Table 3-4. Regression results of investment efficiency

\begin{tabular}{crrrr}
\hline & coefficient & $\begin{array}{c}\text { The value of } \\
\text { T }\end{array}$ & $\begin{array}{c}\text { The value of } \\
\text { Sig }\end{array}$ & VIF \\
\hline (constant) & 0.081 & 1.198 & 0.231 & \\
& & & & \\
Incent & 0.035 & $2.383^{* *}$ & 0.018 & 1.068 \\
Growth & 0.049 & $5.827^{* * *}$ & 0.000 & 1.037 \\
Cash & -0.041 & $-2.366^{* *}$ & 0.018 & 1.212 \\
Roa & 0.007 & 0.146 & 0.884 & 1.178 \\
Size & -0.002 & -0.776 & 0.438 & 1.172 \\
FCF & 0.004 & 1.499 & 0.135 & 1.088 \\
Ownership & 0.029 & 1.493 & 0.136 & 1.196
\end{tabular}

\begin{tabular}{l} 
The \\
adjustment \\
of $\mathrm{R}^{2}$ \\
$\begin{array}{l}\text { F-measure } \\
\text { The value } \\
\text { of Sig }\end{array}$ \\
\hline Note:"***" stands for "p<0.01", "**" stands for $\mathrm{p}<0.05$, and $*$ stands for \\
$\mathrm{p}<0.1$
\end{tabular}

In order to further confirm the relationship between equity incentive and excessive and insufficient investment, we divide the regression results of the last step into positive and negative residuals two groups. Then we make regression of investment efficiency (InvEff). Grouping regression results are shown in table 3-5:

It can be seen from table 3-5, in the underinvestment group, the coefficient of equity incentive is positive and does not pass the coefficient test, which indicates that enterprise underinvestment was not eased with equity incentive increase. It is consistent with the conclusion before. This may be due to the conditions of China's capital market that equity incentive measures are difficult to be efficient and management is more difficult to increase their own interests by investing in the projects whose net present value is positive. So the management is not committed to improving investment efficiency. Thus, the implementation of equity incentive policies of listed companies cannot alleviate the underinvestment. According to the data in the table, the coefficients of other control variables are significant except ROA and Size, indicating that the growth of enterprise performance, the adequacy of cash flow and the concentration of ownership have an impact on the investment efficiency. The coefficients of variance expansion (VIF) are no more than 10. So it is possible to know that multicollinearity does not exist among these variables, and it is feasible to carry out multivariate regression analysis.

In the overinvestment group, the model is significant. At the $95 \%$ confidence level, Growth and equity incentive were significant, while FCF, Cash, Roa, Size and Ownership were not significantly related to excessive investment behavior. The equity incentive coefficient is positive and can pass the $t$ test. It shows that the equity incentive will promote the overinvestment behavior of enterprises, which is consistent with the previous conclusions. It shows that equity incentive plan cannot inhibit the overinvestment behavior of the enterprises. Management can still use the power to pursue the expansion of enterprise and its own benefit, resulting in deviation from the normal investment. Excessive investment is more serious. FCF did not pass the significant test of regression coefficients, probably because of the company's cash flow relatively stable. Even if the enterprise profitability is not high, it can still obtain the capital that is necessary for business activities from market funding. So the investment cash required does not have much relationship with the enterprise free cash flow of last year. The coefficient of variance expansion (VIF) is no more than 10 , indicating that there is no collinearity. To sum up, assume that $\mathrm{H} 1$ is correct.

Table 3-5. Regression results of the investment group and the over investment group

\begin{tabular}{|c|c|c|c|c|c|c|c|c|}
\hline \multirow[b]{2}{*}{ Model } & \multicolumn{3}{|c|}{ Underinvestment group } & \multicolumn{5}{|c|}{ Over investment group } \\
\hline & coefficient & $\begin{array}{l}\text { The } \\
\text { value of } \\
T\end{array}$ & $\begin{array}{l}\text { The } \\
\text { value } \\
\text { of } \\
\mathrm{Sig}\end{array}$ & VIF & coefficient & $\begin{array}{c}\text { The } \\
\text { value of } \\
T\end{array}$ & $\begin{array}{c}\text { The } \\
\text { value } \\
\text { of } \\
\text { Sig }\end{array}$ & VIF \\
\hline constant & 0.028 & 0.504 & 0.615 & & 0.202 & 1.317 & 0.189 & \\
\hline Incent & 0.006 & 0.460 & 0.646 & 1.029 & 0.081 & $2.457 * *$ & 0.015 & 1.213 \\
\hline Growth & 0.038 & $5.459 * * *$ & 0.000 & 1.040 & 0.077 & $3.986 * * *$ & 0.000 & 1.091 \\
\hline Cash & -0.044 & 3.032***- & 0.003 & 1.229 & -0.029 & -0.776 & 0.439 & 1.241 \\
\hline Roa & -0.004 & -0.099 & 0.921 & 1.192 & 0.084 & 0.581 & 0.562 & 1.166 \\
\hline Size & 0.000 & -0.017 & 0.986 & 1.158 & -0.009 & -1.299 & 0.195 & 1.331 \\
\hline FCF & 0.004 & $1.726 *$ & 0.085 & 1.069 & -0.002 & -0.309 & 0.757 & 1.161 \\
\hline Ownership & 0.036 & $2.191^{* *}$ & 0.029 & 1.150 & 0.043 & 1.014 & 0.312 & 1.308 \\
\hline $\begin{array}{l}\text { adjustment } \\
\text { of } R^{2}\end{array}$ & & 0.114 & & & & 0.106 & & \\
\hline F-measure & & 6.558 & & & & 4.224 & & \\
\hline $\begin{array}{c}\text { The value of } \\
\text { Sig }\end{array}$ & & 0.000 & & & & 0.000 & & \\
\hline
\end{tabular}

The 495 samples are divided into state-owned holding (46 observations) and non state-owned holding (449 measurements) two groups, and use model (3-3) to do regression analysis of equity incentive and investment efficiency. Take the absolute value of the regression residuals RES1 as the variable InvEff. The less InvEFf value is, the more likely that corporate investment is within the predictable scope, the less is overinvestment or underinvestment. The regression results are shown in table 3-6:

In the state-owned sample group, the adjusted R2is 0.180 and the Sig value is less than 0.05 , which shows that the model is well fitted. At the $90 \%$ confidence level, the ownership concentration passed $\mathrm{T}$ test. At $95 \%$ confidence level, equity incentive passed $\mathrm{T}$ test. The reason for this phenomenon lies in the special ownership structure of stateowned enterprises in China. The restriction of the market conditions and the property right of the state-owned enterprise of our country makes the companies implement equity incentive carefully. At the present stage of our country's legal system and market condition, state-owned assets supervision and Administration Commission will launch equity incentive promotion activities only when the effect of equity incentive is significant initially and it is beneficial to improve the performance of state-owned enterprises and the reform of state-owned enterprises. The coefficient of equity incentive is significant, which shows that equity incentive has a negative impact on corporate investment efficiency in state-owned holding enterprises. It shows that the implementation of equity incentive plan can not improve the investment efficiency. For the development of enterprises, enterprises should reduce the implementation of equity incentive plans. In the non-state sample group, the sample size is relatively large. Non-stateowned holding enterprises have strong market competitiveness and the enough motion to survive and develop under the 
suppression of shareholders and creditors. Therefore, they are more boldly to absorb corporate governance experience from the developed countries, taking equity incentive measures to achieve corporate profit targets. In the non state-owned holding group, the adjusted R2 is 0.078 , but the explanatory power is not strong. The Sig value is 0.000 , and the model is significant at the $1 \%$ level. Under the confidence level of $90 \%$, the growth rate of business income, management equity incentive, monetary assets ratio are significant, and enterprise scale, ownership concentration, coefficient of free cash flow, asset net interest rate are not significant. The regression results are generally good. It shows that, although equity incentive still has a negative impact on non-state enterprises, the overall negative impact is small. In addition, the improvement of the monetary assets ratio of non-state-owned enterprises can promote investment efficiency. The good assets structure of an enterprise can improve the efficiency of capital utilization and improve the investment efficiency. Enterprise profitability increased, but cannot play a positive role. After comparing the results of the state-owned holding group and the non stateowned holding group, it can be seen that the negative effect of equity incentive on the investment efficiency of state-owned holding group is more obvious, which is consistent with the Hypothesis2.

Table 3-6. Regression results of state-owned holding group and non-state-owned holding group

\begin{tabular}{|c|c|c|c|c|c|c|c|c|}
\hline \multirow[b]{2}{*}{ Model } & \multicolumn{4}{|c|}{ State-owned holding group } & \multicolumn{4}{|c|}{ Non-state holding group } \\
\hline & coefficient & $\begin{array}{l}\text { The } \\
\text { value } \\
\text { of } \mathrm{T}\end{array}$ & $\begin{array}{l}\text { The } \\
\text { value } \\
\text { of } \\
\text { Sig }\end{array}$ & VIF & coefficient & $\begin{array}{l}\text { The } \\
\text { value } \\
\text { of T }\end{array}$ & $\begin{array}{l}\text { The } \\
\text { value } \\
\text { of } \\
\text { Sig }\end{array}$ & VIF \\
\hline constant & -0.567 & -1.348 & 0.186 & & 0.116 & $1.741^{*}$ & 0.082 & \\
\hline Incent & 0.156 & $2.084 * *$ & 0.044 & 1.274 & 0.024 & $1.666^{*}$ & 0.097 & 1.082 \\
\hline Growth & 0.054 & 1.253 & 0.218 & 1.281 & 0.046 & 5.535 *** & 0.000 & 1.040 \\
\hline Cash & -0.141 & -1.111 & 0.274 & 1.477 & -0.035 & $-2.079 * *$ & 0.038 & 1.205 \\
\hline Roa & -0.077 & -0.502 & 0.618 & 1.548 & 0.019 & 0.316 & 0.752 & 1.247 \\
\hline Size & 0.022 & 1.206 & 0.235 & 1.290 & -0.003 & -1.181 & 0.238 & 1.188 \\
\hline FCF & 0.021 & 1.059 & 0.296 & 1.488 & 0.003 & 1.233 & 0.218 & 1.061 \\
\hline Ownership & 0.214 & $1.940^{*}$ & 0.060 & 1.364 & 0.014 & 0.746 & 0.456 & 1.200 \\
\hline $\begin{array}{l}\text { The } \\
\text { adjustment } \\
\text { of R2 }\end{array}$ & \multicolumn{4}{|c|}{0.180} & \multicolumn{4}{|c|}{0.078} \\
\hline F-measure & \multicolumn{4}{|c|}{2.416} & \multicolumn{4}{|c|}{6.388} \\
\hline $\begin{array}{l}\text { The value } \\
\text { of Sig }\end{array}$ & \multicolumn{4}{|c|}{0.038} & \multicolumn{4}{|c|}{0.000} \\
\hline
\end{tabular}

In order to test the moderating effect that company size has on equity incentive and investment efficiency, this paper uses three multiple regression analysis. Here, we do not distinguish between overinvestment or underinvestment groups. The results of the three regression results are shown in table 3-7. In order to avoid the differences caused by variable units, this paper standardized the variables.

As shown in table $3-7$, the sig values are all less than $1 \%$, which suggests that the three models basically meet the effectiveness. In addition, as shown in table 3-7, the cross factor coefficient of Size and Incent is 0.005 , and significant at the $90 \%$ confidence level. When the interaction item is added, the model's R2 increased. In addition, we can compare the results of the three regressions. In the last regression, the equity incentive coefficient is the smallest, which means in the third model, enterprise equity incentive has the least negative effect on investment efficiency. Thus, company size plays a moderating role on the relationship between equity incentive and investment efficiency. The bigger company size is, the more negative effect will be reduced that equity incentive has on corporate investment efficiency. Hypothesis 3 is correct. This shows that in large companies, information is more transparent, which alleviate the negative reaction caused by the excessive managerial power to a certain extent. Business owners should expand the enterprise scale, increase the quality of information disclosure of enterprises, and ultimately improve the investment efficiency.

Table 3-7. results of the three regressions

\begin{tabular}{|c|c|c|c|c|c|c|c|c|c|}
\hline \multirow[b]{2}{*}{ Model } & \multicolumn{3}{|c|}{ Model 1} & \multicolumn{3}{|c|}{ Model 2} & \multicolumn{3}{|c|}{ Model 3} \\
\hline & coefficient & $\begin{array}{c}\text { The } \\
\text { value of } \\
\mathrm{T}\end{array}$ & $\begin{array}{c}\text { The } \\
\text { value } \\
\text { of } \\
\text { Sig }\end{array}$ & coefficient & $\begin{array}{c}\text { The } \\
\text { value of } \\
\text { T }\end{array}$ & $\begin{array}{l}\text { The } \\
\text { value } \\
\text { of } \\
\text { Sig }\end{array}$ & coefficient & $\begin{array}{c}\text { The } \\
\text { value of } \\
\text { T }\end{array}$ & $\begin{array}{c}\text { The } \\
\text { value } \\
\text { of } \\
\text { Sig }\end{array}$ \\
\hline constant & 0.029 & $2.293 * *$ & 0.022 & 0.081 & 1.198 & 0.231 & 0.085 & 1.260 & 0.208 \\
\hline Incent & 0.034 & $2.334 * *$ & 0.020 & 0.035 & $2.383^{* *}$ & 0.018 & 0.029 & $1.935^{*}$ & 0.054 \\
\hline Growth & 0.049 & $5.824 * * *$ & 0.000 & 0.049 & $5.827 * * *$ & 0.000 & 0.049 & $5.801 * * *$ & 0.000 \\
\hline Cash & -0.037 & $-2.247^{* * *}$ & 0.025 & -0.041 & $-2.366 * *$ & 0.018 & -0.046 & $200 *$ & 0.009 \\
\hline Roa & 0.013 & 0.272 & 0.786 & 0.007 & 0.146 & 0.884 & 0.018 & $\begin{array}{l}2.624+34 \\
0.354\end{array}$ & 0.723 \\
\hline FCF & 0.004 & 1.419 & 0.157 & 0.004 & 1.499 & 0.135 & 0.004 & 1.524 & 0.128 \\
\hline Ownership & 0.030 & 1.570 & 0.117 & 0.029 & 1.493 & 0.136 & 0.036 & $1.815^{*}$ & 0.070 \\
\hline & & & & -0.002 & -0.776 & 0.438 & -0.003 & -0.882 & 0.378 \\
\hline $\begin{array}{c}\text { ZIncent*ZSize } \\
\text { The } \\
\text { adjustment of }\end{array}$ & & 0.089 & & & 0.088 & & 0.005 & $\begin{array}{l}1.841^{*} \\
0.093\end{array}$ & 0.066 \\
\hline $\begin{array}{c}\mathrm{R} 2 \\
\text { F-measure }\end{array}$ & & 9045 & & & & & & & \\
\hline The value of & & 0.000 & & & 0.000 & & & 0.000 & \\
\hline
\end{tabular}

\section{ROBUSTNESS TEST}

Model 3-2 uses the positive and negative of the regression residuals to distinguish the overinvestment and underinvestment may lead to the inaccuracy of the results. In this paper, the residuals of the model are divided into three equal parts according to the method of Xin[24]. We select the largest group as the overinvestment group and the smallest group as the underinvestment group. We do the metering analysis by the divided group. The results show that the relationship between equity incentive and investment efficiency is not significant in the underinvestment group. However, there is a negative relationship between equity incentive and investment efficiency in the overinvestment group. It is consistent with the original conclusions in this paper. It can explain the validity of the conclusions to a certain extent.

In addition, other method is also referred, and Tobin's $Q$ is used to measure the development of listed companies [10]. According to the industry statistics, when Tobin's Q is greater than the median industry, it belongs to the high growth group. If Tobin's Q is less than the median of the industry, it belongs to the low growth group[1]. If the listed company's investment in the high growth group is less than the average level of investment in the low growth group, then the listed companies is underinvestment. Therefore, InvEff is equal to1, otherwise 0 . Similarly, if the listed company's investment in the lowgrowth group is greater than the average level of investment in the high growth group, then the listed company that overinvestment. Therefore, InvEff is equal to 1 , otherwise 0 . The regression model is constructed as shown in Equation 4-1, which examines the impact of the firm's equity incentive on under-investment and over-investment, where Institution represents the proportion of institutional investors' shareholding and Property represents the property right ratio. The regression results are shown in Table 4-1. 
InvEff $=\beta_{0}+\beta_{1}$ Incent $+\beta_{2}$ Growth $+\beta_{3}$ Size $+\beta_{4}$ Lev $+\beta_{5}$ Institution $+\beta_{6}$ Property $+\theta_{\mathrm{it}}$ (4-1)

Table 4-1. Robustness test

\begin{tabular}{|c|c|c|c|c|c|c|}
\hline \multirow{2}{*}{ Model } & \multicolumn{3}{|c|}{ Under-investment } & \multicolumn{3}{|c|}{ Over-investment } \\
\hline & coefficient & $\mathrm{t}$-value & Sig & coefficient & $\mathrm{T}$-value & Sig \\
\hline Constant & 0.280 & 0.325 & 0.746 & 1.218 & $1.679 *$ & 0.095 \\
\hline Incent & -0.121 & -0.775 & 0.439 & 0.350 & $1.787 *$ & 0.075 \\
\hline Growth & -0.019 & -0.235 & 0.814 & 0.442 & $3.319^{* * *}$ & 0.001 \\
\hline Lev & -0.892 & $-2.443 * *$ & 0.015 & 0.030 & 0.099 & 0.922 \\
\hline Size & 0.031 & 0.751 & 0.454 & -0.045 & -1.298 & 0.196 \\
\hline Instution & -0.214 & -1.431 & 0.154 & 0.065 & 0.414 & 0.679 \\
\hline Property & 0.181 & 1.721 & 0.087 & -0.060 & -1.038 & 0.300 \\
\hline Adj-R ${ }^{2}$ & & 0.020 & & & 0.060 & \\
\hline F-value & & 1.808 & & & 3.451 & \\
\hline Sig & & 0.099 & & & 0.003 & \\
\hline
\end{tabular}

As shown in Table 4-1, there is no significant relationship between equity incentive and investment efficiency in the underinvestment group. There is a negative relationship between equity incentive and investment efficiency in the overinvestment group. This conclusion is still consistent with the original conclusion. Equity incentives can neither help to curb over-investment nor ease the under-investment.

In order to explore endogenous problems of the impact of equity incentive on investment efficiency, we take the method of Luo (2008) as reference to use equity incent as the independent variable [5]. The basic model $4-2$ is built as follows:

Incent $=\beta_{0}+\beta_{1}$ InvEff $+\beta_{2}$ control $+\beta_{3}$ Return $+\beta_{4}$ lev $+\beta_{5} P A Y+\beta_{6} F C F+\theta_{\text {it }}$ (4-2)

As shown in model 4-2, control represents the nature of the controlling shareholding in the firm, the state-owned enterprise is 1 , and the non-state-owned enterprise is 0. PAY represents the natural logarithm of managerial pay. We use model 3-3 and model 4-2 as the simultaneous equations, and we do the empirical test in the overinvestment group and the underinvestment group respectively. The results are shown in Table 4-2 and Table 4-3:

As shown in Table 4-2, the impact of investment efficiency on equity incentives is not significant at $95 \%$ confidence level, and equity incentives have a significant impact on investment efficiency at $95 \%$ confidence level. The equity incentives have a negative impact on investment efficiency. In other words, equity incentives cannot play a role in restraining overinvestment. It is consistent with our findings. The above conclusions can prove the reliability of the conclusions to a certain extent.

As shown in Table 4-3, at 95\% confidence level, the impact of investment efficiency on equity incentive is not significant, and the impact of equity incentive on investment efficiency is not significant. Equity incentive cannot play a role in alleviating the underinvestment, which is consistent with our findings. The above conclusions can prove the reliability of the conclusions to a certain extent.

Table 4-2. The results on endogeneity test of overinvestment

\begin{tabular}{|c|c|c|c|c|c|c|c|}
\hline \multirow{2}{*}{$\begin{array}{c}\text { Independent } \\
\text { variable } \\
\text { Variable }\end{array}$} & \multicolumn{3}{|c|}{ Incent } & \multirow{2}{*}{$\begin{array}{c}\text { Independent } \\
\text { variable } \\
\text { Variable }\end{array}$} & \multicolumn{3}{|c|}{ InvEff } \\
\hline & Coefficient & T-value & $\mathrm{Sig}$ & & Coefficient & T-value & $\mathrm{Sig}$ \\
\hline Constant & 0.763 & $2.064^{* * *}$ & 0.040 & Constant & 0.202 & 1.317 & 0.189 \\
\hline InvEff & 0.247 & 1.582 & 0.115 & Incent & 0.081 & $2.457^{* * *}$ & 0.015 \\
\hline Control & -0.064 & -1.530 & 0.127 & FCF & -0.002 & -0.309 & 0.757 \\
\hline Return & 0.022 & 1.293 & 0.197 & Growth & 0.077 & $3.986^{* * * *}$ & 0.000 \\
\hline Lev & 0.341 & $4.459^{\text {*决水 }}$ & 0.000 & Size & -0.009 & -1.299 & 0.195 \\
\hline PAY & -0.042 & $-1.691^{*}$ & 0.092 & Roa & 0.084 & 0.581 & 0.562 \\
\hline \multirow[t]{2}{*}{ FCF } & 0.031 & $1.900^{*}$ & 0.058 & Cash & -0.029 & -0.776 & 0.438 \\
\hline & & & & Ownership & 0.043 & 1.014 & 0.311 \\
\hline Adj- $R^{2}$ & & 0.167 & & Adj- $R^{2}$ & & 0.106 & \\
\hline $\begin{array}{c}\text { D.W } \\
\text { statistics }\end{array}$ & & 1.833 & & $\begin{array}{c}\text { D.W } \\
\text { statisticc }\end{array}$ & & 1.827 & \\
\hline
\end{tabular}

Table 4-3. The results on endogeneity test of underinvestment

\begin{tabular}{|c|c|c|c|c|c|c|c|}
\hline \multirow{2}{*}{$\begin{array}{c}\text { Independent } \\
\text { variable } \\
\text { Variable }\end{array}$} & \multicolumn{3}{|c|}{ Incent } & \multirow{2}{*}{$\begin{array}{c}\text { Independent } \\
\text { variable } \\
\text { Variable }\end{array}$} & \multicolumn{3}{|c|}{ InvEff } \\
\hline & Coefficient & $\mathrm{T}$-value & Sig & & Coefficient & $\mathrm{T}$-value & Sig \\
\hline Constant & 1.950 & $8.131 * * * *$ & 0.000 & Constant & 0.028 & 0.504 & 0.614 \\
\hline InvEff & -0.127 & -0.531 & 0.596 & Incent & 0.006 & 0.460 & 0.646 \\
\hline Control & -0.006 & -0.162 & 0.871 & FCF & 0.004 & $1.726^{*}$ & 0.085 \\
\hline Return & 0.030 & $2.511^{* *}$ & 0.012 & Growth & 0.038 & $5.459^{* * * *}$ & 0.000 \\
\hline Lev & 0.160 & $2.966 * * * *$ & 0.003 & Size & 0.000 & -0.017 & 0.986 \\
\hline PAY & -0.115 & $\begin{array}{c}- \\
7.243 * * *\end{array}$ & 0.000 & Roa & -0.004 & -0.099 & 0.921 \\
\hline FCF & 0.007 & 0.708 & 0.479 & Cash & -0.044 & $\begin{array}{c}- \\
3.032 * * *\end{array}$ & 0.003 \\
\hline & & & & Ownership & 0.036 & $2.191^{* *}$ & 0.029 \\
\hline Adj- $R^{2}$ & & 0.172 & & Adj- $R^{2}$ & & 0.114 & \\
\hline $\begin{array}{c}\text { D.W } \\
\text { statistics }\end{array}$ & & 1.667 & & $\begin{array}{c}\text { D.W } \\
\text { statistics }\end{array}$ & & 1.885 & \\
\hline
\end{tabular}

\section{CONCLUSIONS}

First, the A-share listed companies on the Shanghai and Shenzhen Stock Exchange from 2006 to 2015 is collected as samples. Second, the effect of the managerial equity incentive on the investment efficiency is examined. The following three conclusions are made in this paper: First, the managerial equity incentives can neither restrict the managerial underinvestment behavior nor restrict the managerial overinvestment. Empirical data show that the managerial equity incentive has a greater negative impact on the investment efficiency of the listed companies, and this negative impact is relatively significant in China's listed companies. The listed companies should reduce the implementation of equity incentive plan in order to protect the efficiency of the investment according to the specific capital market conditions. Second, compared with the state-owned enterprises, the effect of managerial equity incentive is different in the non-state-owned enterprises. We cannot analyze the investment situation of state-owned enterprises in detail due to the small number of state-owned enterprises that implement equity incentive. The active level of equity incentive and investment in the state-owned enterprises is less than it in the non-state-owned enterprises. Therefore, stateowned enterprises should enhance their competitiveness, improve information transparency and reduce equity incentive plan. Non-state-owned enterprises can balance the status quo of enterprise development and discretionary use equity incentive plan. Third, the size of the company will strengthen the relationship between managerial equity incentives and the efficiency of enterprises' investment. In other words, the size of listed companies can modify the relationship between 
managerial equity incentives and the efficiency of enterprises' investment. Specifically, compared with small companies, the negative role of managerial equity incentive is not so strong in the relatively large scale of listed companies. Therefore, the owner of the enterprise can weaken the negative impact of equity incentives by expanding the firm size. It is very necessary for the small-scale enterprises to establish a monitoring mechanism.

The history of equity incentive in the listed companies is not too long. The number of the state-owned enterprises which implement the equity incentive is very small. The insufficient sample may lead to the biased results. There are a variety of different measurement methods to measure the indicators of the investment efficiency. The investment behavior, free cash flow, net cash flow and asset-liability ratio is different in different industry. Therefore, the managerial equity incentive effect in state-owned enterprise and the measurement of investment efficiency may be the future direction of this article.

\section{References}

[1] Wang, J., Cheng, B., Does External Earnings Pressure Influence Under-investment Behavior?-Evidence from the Listed Manufacturing Companies in China. Accounting Research, 95 (3), 2014, 33-40.

[2] Gaver, J. J., Gaver, K. M., Compensation Policy and the Investment Opportunity Set. Financial Management, 24(1), 1995, 19-32.

[3] Wang, Z., Zhang, J. J., Zheng, Q., The Quality of Internal Control, Property Right and Corporate Inefficiency Investment: Evidence from Chinese Listed Companies. Management Review, 27(9), 2015, 95-107.

[4] Roll, R., Schwartz E, Subrahmanyam A. Options Trading Activity and Firm Valuation. Journal of Financial Economics, 94(3), 2009, 345-360.

[5] Luo, F. B., Ran, M. S., Du, J. T., An Empirical Research on the Relationship between Top Executive's Stock based Compensation and Investment Decision. Accounting Research, 95 (8), 2008, 69-76.

[6] Strobl, G., Stock-based Managerial Compensation, Price Informativeness, and the Incentive to Overinvest. Journal of Corporate Finance, 29, 2014, 594-606.

[7] Wang, J., Lu, Y., Zhu, Z. Z., Does Stock Option Plan Induce Over-Investment? Evidence from Listed Companies of Manufacturing on SME Board Market in China. Journal of Audit \& Economics, (5), 2013, 70-79.

[8] Wang, H., Huang, Z. J., Motivating Managers by Offering Stock Option, the Composition of Board of Directors and Enterprises' Value-an Empirical Analysis Based on the View of Intrinsicalness. Management World, 172 (09), 2006, 101-116.

[9] Jensen, M. C., Agency Costs of Free Cash Flow, Corporate Finance, and Takeovers. The American Economic Review, 76 (2), 1986, 323-329.
[10] Arrfelt, M., Wiseman, R. M., Hult, G. T. M., Looking Backward Instead of Forward: Aspiration-Driven Influences on the Efficiency of the Capital Allocation Process. Academy of Management Journal, 56 (4), 2013, 1081-1103

[11] Dutta, S., Nezlobin, A., Dynamic Effects of Information Disclosure on Investment Efficiency. Journal of Accounting Research, 2016, DOI: 10.1111/1475679X.12161.

[12] Lara, J. M. G., Osma, B. G., Penalva, F., Accounting Conservatism and Firm Investment Efficiency. Journal of Accounting \& Economics, 61(1), 2016, 221-238.

[13] Bebchuk, L. A., Fried, J. M., Executive Compensation as an Agency Problem. Journal of Economic Perspectives, 17(3), 2003, 71-92.

[14] Xiao, X., Chen, C., Incentive Level, Monitoring Mechanism, and Equity Incentive Plan in China's Listed Companies. Nankai Business Review, (01), 2013, 24-32.

[15] Quan, X. F., Wu, S. N., Wen, F., Managerial Power, Private Income and Compensation Rigging. Economic Research Journal, (11), 2010, 73-87.

[16] Chen, X. D., Zhou, J. N., Non-incentive Executives' Equity Incentive, Firm Investment Mode and Private Benefits of Control. Management Review, 28(5), 2016, 161-174.

[17] Goldman, E., Slezak, S. L., An Equilibrium Model of Incentive Contracts in the Presence of Information Manipulation. Journal of Financial Economics, 80(3), 2006, 603-626.

[18] Zhang, C. Z., Li, H. Z., Zhao, X. P., Research on relationship among firm scale, managerial discretion and R\&D expenditure : Evidence form Chinese listed companies. Studies in Science of Science, 24(3), 2006, 432-438.

[19] Bhattacharya, N., Investors' Trade Size and Trading Responses Around Earnings Announcements: An Empirical Investigations. The Accounting Review, 76(2), 2001, 221-244.

[20] Core, J. E., Larcker D F. Performance Consequences of Mandatory Increases in Executive Stock Ownership. Journal of Financial Economics, 64(3), 2002, 317-340.

[21] Bergstresser, D., Philippon, T., CEO Incentives and Earnings Management. Journal of Financial Economics, 80(3), 2006, 511-529.

[22] Lv, C. J., Zhang, H. P., The Effect of the Stock Option Plans on Corporate Investment Behaviors. Management World, 188 (11), 2011, 118-126,.

[23] Xu, Q., Stock Options and Corporate Investment Behavior under Uncertainty. Accounting Research, (03), 2014, 41-48, 95.

[24] Xin, Q. Q., Zheng, G. J., Yang, D. M., Business groups, government control and investment efficiency. Journal of Financial Research, (10), 2007, 123-142. 